\title{
INTERMEDIATES IN THE FORMATION OF DICYCLOPENTADIENYLTUNGSTEN DICARBONYL: ROLE OF A DICYCLOPENTADIENYLTUNGSTEN CARBONYL CHLORIDE CATION
}

\author{
LARRY G. BELL and HANS H. BRINTZINGER * \\ Fachbereich Chemie, Universität Konstanz, D-7750 Konstanz (B.R.D.)
}

\section{Summary}

Dicyclopentadienylcarbonyl chloride cations of tungsten and molybdenum, $\left(\mathrm{C}_{5} \mathrm{H}_{5}\right)_{2} \mathrm{M}(\mathrm{CO}) \mathrm{Cl}^{+}(\mathrm{M}=\mathrm{W}, \mathrm{Mo})$ are obtained from a reaction of the corresponding dichlorides with $\mathrm{AlCl}_{3}$ and $\mathrm{CO}$. Reduction of $\left(\mathrm{C}_{5} \mathrm{H}_{5}\right)_{2} \mathrm{~W}(\mathrm{CO}) \mathrm{Cl}^{+}$in the presence of $\mathrm{CO}$ gives the dicarbonyl complex $\left(\mathrm{C}_{5} \mathrm{H}_{5}\right)_{2} \mathrm{~W}(\mathrm{CO})_{2}$. The corresponding molybdenum complex was not obtained under analogous reaction conditions.

\section{Introduction}

Previously we have reported that dicyclopentadienyltungsten dicarbonyl is formed when dicyclopentadienyltungsten dichloride is reduced in the presence of $\mathrm{CO}$ at elevated pressures [1]. The dicarbonyl complex represents, to the best of our knowledge, the only stable carbonyl compound in which the central metal would formally exceed an 18-electron valence-shell configuration if each of the $\mathrm{C}_{5} \mathrm{H}_{5}{ }^{-}$ligands is considered to be a six-electron donor. Alternatively, this compound might be formally in accord with the 18-electron rule, if one of the rings were displaced to a trihapto structure. Even this arrangement would be virtually without precedent, however: structures in which part of the $\pi$-electron population of $a \pi$-bound $C_{6} R_{6}$ or $C_{5} R_{5}{ }^{-}$ligand is displaced from the central metal ion by the effect of $\mathrm{CO}$ ligands have been postulated as intermediates in ligand substitution reactions [2-4], but we are not aware of any stable compounds of this nature *. Because of this relation of $\left(\mathrm{C}_{5} \mathrm{H}_{5}\right)_{2} \mathrm{~W}(\mathrm{CO})_{2}$ to possible unstable intermediates in other reaction systems, we were interested in the mechanisms of formation and stabilization of this unusual coordination compound and have further examined the reaction sequences that lead to its formation.

* A related nitrasyl complex $\left(\mathrm{C}_{5} \mathrm{H}_{5}\right)_{2} \mathrm{MO}(\mathrm{NO}) \mathrm{CH}_{3}$ has been reported by Cotton and Rusholme [5] to have boin $\mathrm{C}_{5} \mathrm{H}_{5}$ rings positioned asymmetrically with respect to tine metal center. 


\section{Results}

When solutions of the monocarbonyl compound $\left(\mathrm{C}_{5} \mathrm{H}_{5}\right)_{2}$ WCO are exposed to $\mathrm{CO}$ pressures of about $100 \mathrm{~atm}$, the dicarbonyl $\left(\mathrm{C}_{5} \mathrm{H}_{5}\right)_{2} \mathrm{~W}(\mathrm{CO})_{2}$ is formed in essentially quantitative yield over a period of $12-15 \mathrm{~h}$; no such transformation is noticeable at atmospheric pressures of $\mathrm{CO}$, however. These observations indicate that $\left(\mathrm{C}_{5} \mathrm{H}_{5}\right)_{2}$ WCO can serve as an intermediate in the formation of $\left(\mathrm{C}_{5} \mathrm{H}_{5}\right)_{2} \mathrm{~W}$ $(\mathrm{CO})_{2}$ at elevated $\mathrm{CO}$ pressures only. However, $\left(\mathrm{C}_{5} \mathrm{H}_{5}\right)_{2} \mathrm{~W}(\mathrm{CO})_{2}$ can be made at atmospheric $\mathrm{CO}$ pressure by a reaction sequence in which the cationic compound $\left(\mathrm{C}_{5} \mathrm{H}_{5}\right)_{2} \mathrm{~W}(\mathrm{CO}) \mathrm{Cl}^{+}$is a key intermediate. Thus when $\left(\mathrm{C}_{5} \mathrm{H}_{5}\right)_{2} \mathrm{WCl}_{2}$ is treated with one equivalent of $\mathrm{AlCl}_{3}$ under carbon monoxide in a chlorobenzene suspension, an orange-tan compound with the composition $\left(\mathrm{C}_{5} \mathrm{H}_{5}\right)_{2} \mathrm{~W}(\mathrm{CO}) \mathrm{Cl}\left(\mathrm{AlCl}_{4}\right)$ is formed. (This compound was characterized by an NMR singlet at $6.32 \mathrm{ppm}$ in $\left(\mathrm{CD}_{3}\right)_{2} \mathrm{SO}$, a strong $\nu(\mathrm{CO})$ absorption at $2050 \mathrm{~cm}^{-1}$ and by its elemental analysis *.) When $\left(\mathrm{C}_{5} \mathrm{H}_{5}\right)_{2} \mathrm{~W}(\mathrm{CO}) \mathrm{Cl}\left(\mathrm{AlCl}_{4}\right)$ is reduced with sodium amalgam in a toluene suspension under carbon monoxide at atmospheric pressure, the dark blue dicarbonyl complex $\left(\mathrm{C}_{5} \mathrm{H}_{5}\right)_{2} \mathrm{~W}(\mathrm{CO})_{2}$ is obtained in $30-40 \%$ yield after removal of solvent and subsequent sublimation. The dicarbonyl obtained in this manner contains no $\left(\mathrm{C}_{5} \mathrm{H}_{5}\right)_{2}$ WCO, as indicated by its IR and NMR spectra. While the dicarbonyl compound is stable thermally, it is very sensitive to photolytic $\mathrm{CO}$ elimination. Its spectrum in a toluene- $d_{8}$ solution did not change when stored in the dark several months.

Mixtures of non-sublimable carbonyl residues with many $\mathrm{CO}$ absorptions in the range $1990-1830 \mathrm{~cm}^{-1}$ were observed as by-products in the reduction of $\left(\mathrm{C}_{5} \mathrm{H}_{5}\right)_{2} \mathrm{~W}(\mathrm{CO}) \mathrm{Cl}\left(\mathrm{AlCl}_{4}\right)$ and in reduction of $\left(\mathrm{C}_{5} \mathrm{H}_{5}\right)_{2} \mathrm{WCl}_{2}$ under $\mathrm{CO}$.

During attempts to increase the yields of $\left(\mathrm{C}_{5} \mathrm{H}_{5}\right)_{2} \mathrm{~W}(\mathrm{CO})_{2}$, we observed that $\left(\mathrm{C}_{5} \mathrm{H}_{5}\right)_{2} \mathrm{~W}(\mathrm{CO})_{2}$ is not stable under the conditions of its formation, i.e. in the presence of sodium amalgam and $\mathrm{CO}$. Under these conditions, it is transformed into mixtures of non-sublimable, presumably polynuclear or anionic carionyl compounds. Among these, the presence of $\left(\mathrm{C}_{5} \mathrm{H}_{5}\right) \mathrm{W}(\mathrm{CO})_{3}{ }^{-}$is indicated by IR absorptions at 1885 and $1760 \mathrm{~cm}^{-1}$.

Treatment of $\left(\mathrm{C}_{5} \mathrm{H}_{5}\right)_{2} \mathrm{MoCl}_{2}$ with $\mathrm{AlCl}_{3}$ under $\mathrm{CO}$ likewise yields the compound $\left(\mathrm{C}_{5} \mathrm{H}_{5}\right)_{2} \mathrm{Mo}(\mathrm{CO}) \mathrm{Cl}\left(\mathrm{AlCl}_{4}\right)$. Reduction of this compound with sodium amalgam under $\mathrm{CO}$ in a toluene suspension does not yield $\left(\mathrm{C}_{5} \mathrm{H}_{5}\right)_{2} \mathrm{Mo}(\mathrm{CO})_{2}$. At atmospheric $\mathrm{CO}$ pressure, $\left(\mathrm{C}_{5} \mathrm{H}_{5}\right)_{2} \mathrm{MoCO}$ is the main reduction product, while reduction at $\mathrm{CO}$ pressures of about 100 atm yields mainly orange-coloured $\left(\mathrm{C}_{5} \mathrm{H}_{5}\right)$ $\left(\mathrm{C}_{5} \mathrm{H}_{7}\right) \mathrm{Mo}(\mathrm{CO})_{2}[1,7]$ and other, non-sublimable carbonyl compounds.

\section{Discussion}

It is unlikely that $\left(\mathrm{C}_{5} \mathrm{H}_{5}\right)_{2} \mathrm{WCO}$ is an intermediate in the reduction of $\left(\mathrm{C}_{5} \mathrm{H}_{5}\right)_{2}$ $\mathrm{W}(\mathrm{CO}) \mathrm{Cl}^{+}$to $\left(\mathrm{C}_{5} \mathrm{H}_{5}\right)_{2} \mathrm{~W}(\mathrm{CO})_{2}$, since the monocarbonyl is not converted into the dicarbonyl under these conditions, i.e. under $\mathrm{CO}$ at atmospheric pressure. More probably the second $\mathrm{CO}$ ligand is taken up at an oxidation state of the tungsten centre, which is still higher than $+I I$, and is then fixed into its position by a

"1 Related compounds, $\left(\mathrm{C}_{5} \mathrm{H}_{5}\right)_{2} W(\mathrm{CO}) \operatorname{Br}\left(\mathrm{PF}_{6}\right)$ and its molybdenum analogue, are produced by a reaction of $\left(\mathrm{C}_{5} \mathrm{H}_{5}\right)_{2} \mathrm{~W}\left(\mathrm{~S}_{\left.\left(\mathrm{CH}_{3}\right)_{2}\right) \mathrm{Br}(\mathrm{PF}}\right)$ with $\mathrm{CO}$ [6]. 
subsequent reduction step. A dication $\left(\mathrm{C}_{5} \mathrm{H}_{5}\right)_{2} \mathrm{~W}(\mathrm{CO})_{2}{ }^{2+}$, present in small amounts in equilibrium with $\left(\mathrm{C}_{5} \mathrm{H}_{5}\right)_{2} \mathrm{~W}(\mathrm{CO}) \mathrm{Cl}^{+}$and $\mathrm{CO}$, could conceivable be the actual substrate in the reduction process. The observation that $\left(\mathrm{C}_{5} \mathrm{H}_{5}\right)_{2} \mathrm{~W}(\mathrm{CO})_{2}$ decomposes under the conditions of its formation to $\left(\mathrm{C}_{5} \mathrm{H}_{5}\right) \mathrm{W}(\mathrm{CO})_{3}{ }^{-}$and other degradation products is in accord with the view that this dicarbonyl compound is an intermediate in a reductive ring elimination reaction (eq. 1 ).

$\left(\mathrm{C}_{5} \mathrm{H}_{5}\right)_{2} \mathrm{~W}(\mathrm{CO}) \mathrm{Cl}^{+} \cdot \stackrel{\mathrm{CO}_{2} 2^{-}}{-\mathrm{Cl}^{-}}\left(\mathrm{C}_{5} \mathrm{H}_{5}\right)_{2} \mathrm{~W}(\mathrm{CO})_{2} \underset{-\mathrm{C}_{5} \mathrm{H}_{5}^{-}}{\stackrel{\mathrm{CO}_{2} \mathrm{e}^{-}}{\longrightarrow}}\left(\mathrm{C}_{5} \mathrm{H}_{5}\right) \mathrm{W}(\mathrm{CO})_{3}{ }^{-}$

Interestingly, the monocarbonyl compound $\left(\mathrm{C}_{5} \mathrm{H}_{5}\right)_{2} \mathrm{WCO}$ is completely resistant towards such reductive ring elimination. The bonding features which cause disparity in thermal stability between $\left(\mathrm{C}_{5} \mathrm{H}_{5}\right)_{2} \mathrm{~W}(\mathrm{CO})_{2}$ and its molybdenum analogue remain to be determined. They are undoubtedly related, however, to the increased reactivity of $\left(\mathrm{C}_{5} \mathrm{H}_{5}\right)_{2} \mathrm{~W}$ derivatives in a number of reactions of potential interest for homogeneous catalysis $[8,9]$.

\section{Experimental}

Except for the stable starting materials $\left(\mathrm{C}_{5} \mathrm{H}_{5}\right)_{2} \mathrm{WCl}_{2}$ and $\left(\mathrm{C}_{5} \mathrm{H}_{5}\right)_{2} \mathrm{MoCl}_{2}$ [10] all the substances reported were handled under $\mathrm{N}_{2}$, either by Schlenk or vacuum-line techniques. Solvents were dried with $\mathrm{LiAlH}_{4}$ and distilled in vacuo.

1. $\left(\mathrm{C}_{5} \mathrm{H}_{5}\right)_{2} \mathrm{~W}(\mathrm{CO}) \mathrm{Cl}\left(\mathrm{AlCl}_{4}\right)$ and $\left(\mathrm{C}_{5} \mathrm{H}_{5}\right)_{2} \mathrm{Mo}(\mathrm{CO}) \mathrm{Cl}\left(\mathrm{AlCl}_{4}\right)$. A sample of $\left(\mathrm{C}_{5} \mathrm{H}_{5}\right)_{2}-$ $\mathrm{WCl}_{2}(285 \mathrm{mg}, 0.744 \mathrm{mmol})$ is stirred, together with $99 \mathrm{mg}(0.744 \mathrm{mmol})$ of freshly sublimed $\mathrm{AlCl}_{3}$ in $40 \mathrm{ml}$ of chlorobenzene under 1 atm of $\mathrm{CO}$ pressure. The solid material gradually changes in colour from dark-green to orange-tan. After about $3-4 \mathrm{~h}$, the solvent is removed and the residue washed with petroleum ether and dried in vacuo at room temperature. It consists of pure $\left(\mathrm{C}_{5} \mathrm{H}_{5}\right)_{2} \mathrm{~W}(\mathrm{CO})$ $\mathrm{Cl}\left(\mathrm{AlCl}_{4}\right)$ (NMR: singlet, $\delta 6.32 \mathrm{ppm}$ in DMSO; IR: $\nu(\mathrm{CO})$ at $2050 \mathrm{~cm}^{-1}$ in nujol) m.p. $230^{\circ} \mathrm{C}$ (decomp.). It is fairly stable in air, but rather hygroscopic. Elemental analysis: Found: $\mathrm{C}, 24.02 ; \mathrm{H}, 1.88 ; \mathrm{Al}, 5.05 ; \mathrm{Cl}, 32.30 ; \mathrm{W}, 33.41 . \mathrm{C}_{11} \mathrm{H}_{10} \mathrm{AlCl}_{5} \mathrm{OW}$ calcd.: C, $24.18 ; \mathrm{H}, 1.85 ; \mathrm{Al}, 4.94 ; \mathrm{Cl}, 32.45 ; \mathrm{W}, 33.65 \%$.

If the same procedure is carried out in toluene some samples of $\left(\mathrm{C}_{5} \mathrm{H}_{5}\right)_{2} \mathrm{WCl}_{2}$ fail to react. This appears to arise from decreased solubility due to variations in crystal size. Similar observations were made in the direct reduction of $\left(\mathrm{C}_{5} \mathrm{H}_{5}\right)_{2} \mathrm{WCl}_{2}$ to $\left(\mathrm{C}_{5} \mathrm{H}_{5}\right)_{2} \mathrm{~W}(\mathrm{CO})_{2}$ under higher $\mathrm{CO}$ pressures.

The preparation of $\left(\mathrm{C}_{5} \mathrm{H}_{5}\right)_{2} \mathrm{Mo}(\mathrm{CO}) \mathrm{Cl}\left(\mathrm{AlCl}_{4}\right)$ is analogous to that for the tungsten analogue. $\left(\mathrm{C}_{5} \mathrm{H}_{5}\right)_{2} \mathrm{Mo}(\mathrm{CO}) \mathrm{Cl}\left(\mathrm{AlCl}_{4}\right)$ is a tan-colored material, melting with decomposition at $170^{\circ} \mathrm{C}$ (NMR: singlet, $\delta 6.36 \mathrm{ppm}$ in DMSO; IR: $\nu(\mathrm{CO})$ at $2055 \mathrm{~cm}^{-1}$ in nujol). Elemental analysis: $\mathrm{C}, 28.90 ; \mathrm{H}, 2.38 ; \mathrm{Al}, 5.97 ; \mathrm{Cl}$, 38.65; Mo, 20.79. $\mathrm{C}_{11} \mathrm{H}_{10} \mathrm{AlCl}_{5} \mathrm{OMo}$ calcd.: $\mathrm{C}, 28.82 ; \mathrm{H}, 2.20 ; \mathrm{Al}, 5.89 ; \mathrm{Cl}$, 38.67; Mo, $20.92 \%$.

2. $\left(\mathrm{C}_{5} \mathrm{H}_{5}\right)_{2} \mathrm{~W}(\mathrm{CO})_{2}$. To a suspension of $0.58 \mathrm{mmol}$ of $\left(\mathrm{C}_{5} \mathrm{H}_{5}\right)_{2} \mathrm{~W}(\mathrm{CO}) \mathrm{Cl}\left(\mathrm{AlCl}_{4}\right)$, obtained by treatment of $224 \mathrm{mg}$ of $\left(\mathrm{C}_{5} \mathrm{H}_{5}\right)_{2} \mathrm{WCl}_{2}$ and $78 \mathrm{mg} \mathrm{AlCl} 3$ in $40 \mathrm{ml}$ of toluene is added $1.2 \mathrm{ml}$ of a $1 M$ solution of sodium amalgam. The mix ture is stirred under $1 \mathrm{~atm}$ of CO pressure for $15 \mathrm{~h}$. The dark solution formed is filtered from the residue of solids and mercury. After removal of solvent, the residue is sublimed at $45^{\circ} \mathrm{C}$. The blue material obtained is identified as $\left(\mathrm{C}_{5} \mathrm{H}_{5}\right)_{2} \mathrm{~W}(\mathrm{CO})_{2}$ by its spectral properties [1] (NMR: singlet, $\delta 5.17 \mathrm{ppm}$ in toluene-d $d_{8} ; \mathrm{IR}: \nu(\mathrm{CO})$ 
at 1.872 and $1955 \mathrm{~cm}^{-1}$ in nujol; mass peaks for $\left(\mathrm{C}_{5} \mathrm{H}_{5}\right)_{2} \mathrm{~W}(\mathrm{CO})_{2}{ }_{2},\left(\mathrm{C}_{5} \mathrm{H}_{5}\right)_{2} \mathrm{~W}$ $(\mathrm{CO})^{+}$and $\left(\mathrm{C}_{5} \mathrm{H}_{5}\right)_{2} \mathrm{~W}^{+}$with appropriate isotope distributions).

\section{Acknowledgements}

Financial support for this work by Deutsche Forschungsgemeinschaft and by Fonds der Chemischen Industrie is gratefully acknowledged. Helpful comments are due to Prof. Richard R. Schrock.

\section{References}

1 I5.L.T. Wong and H.H. Brintzinger, J. Amer. Chem. Soc., 97 (1975) 5143.

2 1.W. Stolz, H. Haas and R.K. Sheline. J. Amer. Chem. Soc., 87 (1965) 716.

3 F. Zingales, A. Chiesa and F. Basolo, J. Amer. Chem. Soc., 88 (1966) 2707.

4 11. Werrer and R. Prinz, J. Organometal. Chem., 5 (1966) 79.

5 F.A. Cotton and G.A. Rusholme, J. Amer. Chem. Soc., 94 (1972) 402.

6 M.L.H. Green, R.E. Mackenzie and J.S. Poland, J. Chem. Soc. A, (1976) 1993.

7 F.W.S. Benfield. R.A. Forder, M.L.H. Green, G.A. Moser and K. Prout, Chem. Commun., (1973) 759.

8 K.L.T. Wong. J.L. Thomas and H.H. Brintzinger, J. Amer. Chem. Soc., 96 (1974) 3694.

9 I.1. Ephritikhine and M.L.H. Green, Chem. Commun., (1976) 926.

10 R.I. Cooper and A.L.H. Green, Z. Naturforsch., B, 19 (1964) 652. 